\title{
The Language Interference in English Speaking Skill for EFL Learners
}

\author{
Dedy Subandowo \\ English Education Study Program \\ Muhammadiyah University of Metro \\ Lampung, Indonesia \\ dedy.subandowo@pbiummetro.ac.id
}

\begin{abstract}
This paper examines the language interference in English speaking skill. The interference was influenced by the mother tongue of the learners. Therefore, this study explains the forms of language interference in the students' speaking skill and the factors affecting the language interference. In addition, the study attempts to use case study with descriptive qualitative research approach. The data were collected by using the questionnaire and recording technique. The data, then, were analyzed based on the students 'sound production. Subsequently, The data were formulated on the table illustrating the spread of the students' interference. In identifying the students' sounds, three classifications of the English pronunciation were applied. The result shows that most of the students made error in their pronunciation, $2 \%$ of consonants and 3\% of vowel. The student's sound production did many mistakes in their pronunciation started from consonants to vowel sound. The mistakes in consonant sounds caused by the mother tongue were highly interfered. The pronunciation in manner of articulation occurred in consonants such as plosive and nasal sounds. Moreover, for the place of articulation, the errors appeared on dental and palate-alveolar. The factors influencing the mother tongue interference in the students' pronunciation are the environment, students' motivation, and the language sound system.
\end{abstract}

Keywords: Language interference, Mother Tongue, Pronunciation, Speaking Skill, Vowels and Consonants

\section{INTRODUCTION}

The Indonesian sounds systems that might not produce the sounds like fricative- dental (/ð, / $/$ /) and fricative labio- dental $(/ \mathrm{v} /)$ and many other sounds tend to make problems for the EFL learners specifically in pronunciation which has important role in speaking [16], [9]. The sounds of /ð/ in "than" and / $\theta /$ in "thank $k^{\text {ee }}$ are replaced by $/ \mathrm{t} /$ and $/ \mathrm{v} /$ in "visual" is replaced by /f/. This kind of problem does matter because the Indonesian tongue has some difficulties to pronounce /v/ rather than /f/. Therefore, students have a tendency to pronounce more /f/ when they find $/ \mathrm{v} /$ for instance, the word "very" is pronounced as /feri/ instead of /veri/. What is more, they are also sometimes pronouncing the word "the" as /nðe/.

Based on the observation, there are three possible assumptions of the problems that can be seen from the students' speaking ability. First, the students are difficult to distinguish among the similar sounds. Second, the students are difficult to produce accepted English pronunciation, and the last is they tend to find difficulties in uttering the sounds that Indonesians do not have such as, /ov/ and / $/ 3 /$ which cannot be distinguished clearly in Indonesian, and the sounds are united to be clear /ov/, for example / $\mathrm{z} /$ in "zero"/ /e"ziərəo/ and / $/ 3 /$ in "genre"e/za:nro/. It is then related to the language error. The problems in uttering English by Indonesian students are because their mother tongue (L1) influences their capability in producing English. They only generalize the L2 sounds based on their L1.

\section{A. Mother Tongue}

Mother tongue largely refers to not only the language one learns from one's mother but also the speaker's dominant and home language. It's also called native language [4]. The differences of mother tongue between one and another are the characteristics that we should look for in language learning process. Pronunciation errors exhibit more in the first language influence that does speaking errors although a substantial number of the first language. Pronunciation errors which are made by children are similar to those who are made by monolingual first language learners and only small proportions of pronunciation error in speaking are traceable to the first language learners. First language is as a foundation on which you can build an understanding of principles of foreign language. Extensive research has already been done in the area of native language interference on the target language. So, mother tongue is native language from our habit that come the surface structure of the first language to the surface of target language. On the other hand, mother tongue has both potentially positive and negative consequences [1]. This is proved by the students when doing the activity in groups; they tend to use their mother tongue instead of English all the time. This action would bring their identity. Meanwhile, the negative impact of that too much reliance on the $\mathrm{L} 1$ may undermine the interaction in English [6]. 


\section{B. The Concept of Interference}

Language transfer (also known as L1 interference, linguistic interference, and cross meaning) refers to speakers or writers applying knowledge from their native language to a second language. Interference is effect that is given by process of the other language learning because of learner's language background. In addition, the interference arises from possessing two simultaneously active languages by inhibiting the language that is tasking inappropriate or enhancing the activation of the language they intend to use [8]. As nearly all new skills are learned on the basis of existing skill, skill research has traditionally shown a keen interest in the phenomenon of transfer. Language interference is the effect of language learners' first language on their production of the language they are learning. It means that the speaker's first language influences his/her second or and his/her foreign language [7].

\section{Mother Tongue Interference}

The concept of mother tongue interference can be viewed as a transfer that affects learning both negatively and positively. It means that there is possibility for the learners to produce some mistakes or errors in learning a second language especially English. This idea is supported that there is high probability of cross-linguistic influence in second language acquisition and this influence may produce some errors which are caused by negative transfer [12]. Furthermore, mispronunciation and grammatical errors are the most common types of interference between the mother tongue and the target language [11]. In so doing, the language interference in pronunciation means as a result, Interference refers to the problem that students present in oral speech activities in aspects related to the correct pronunciation of English sounds [14].

\section{Concept of Pronunciation}

Pronunciation simplifies organized sounds of language produced by human speech organ using all the phonemics units of the language as well, which is maintaining all the phonemic units of the language by means of the distinctive units of the distinctive phonemic features [10]. It can be easily understood that pronunciation is a way in which someone utter the words or the language to another based on the available rules, i.e. sound, intonation and rhythm [5].

\section{E. English Language Learning}

Studying English as foreign language is fundamental for the necessity presented in this globalized world. This language has spread widely as the international language. Therefore, it has different function in communication such as business, travel or studies without the country. However, English has become a subject in the majority of schools in Indonesia and students tend to have some problems at the moment of articulate English sounds due to the phonological interference [2].

\section{F. Speaking Skill}

Speaking can be seen as the act of expressing thought, ideas, and feelings by using audible symbols or visible bodily action. In addition, the use of demonstration and audio visual are also could be effectively used to raise speaking skill [15]. Therefore, speaking is regarded as the most crucial skill among other four language skills and central one as it enables the learner to establish successful communication in that language, which is often the main aim of learning any foreign language [13].

\section{METHOD}

This research was designed as a case study at Muhammadiyah University of Metro with the second semester students as the subject of the research with the total population of 40 students. It was aimed at describing the students' mother tongue interference in pronunciation in speaking ability. The data were collected through questionnaire and record. The material of the pronunciation was designed to measure the students' ability in pronouncing the English in speaking ability especially. The students were given word lists and sentences consisting of all of pronunciation that should be pronounced based on every phonetic symbol of the word. Subsequently, the finding data were analyzed based on the students' sounds that have been recorded since this research was done to help the students face their mistakes in pronouncing the English sounds. The data were formulated in table illustrating the spread of the students' interference. In identifying the students' sounds, three classifications of the English pronunciation were applied.

\section{A. Error Pronunciation}

\section{FINDING AND DISCUSSION}

The study found some mistakes in students' pronunciation when they recorded their voice. From the description, it can be inferred that from 24 consonants from 40 students as the source of data, there were many mistakes that they did when they pronounced consonants / $\mathrm{t} /$ and $/ 3$ I, that is $2 \%$. They did mistake as many as $3 \%$ when they pronounced $/ \mathrm{d} z /, / \mathrm{v} /, / \mathrm{z} /$ and $/ \mathrm{r} /$. There is $4 \%$ of mistake that students have made when they spoke $/ \mathrm{b} /, / \mathrm{k} /, / \mathrm{g} /, / \theta /, / \mathrm{h} /$, $/ \mathrm{m} /, / \mathrm{n} /, / 1 /, / \mathrm{w} /$. Then $5 \%$ of mistake was done when they spoke $/ \mathrm{p} /, / \mathrm{t} /, / \mathrm{d} /, / \mathrm{f} /, / \mathrm{d} /$, and $/ \mathrm{p} /$. For the sounds of $/ \mathrm{s} /, / \mathrm{J} /$ and $/ y /$, the total mistake was around $6 \%$. It can be concluded that if the percentage of sounds is low, the words interfered by the mother tongue is high. Otherwise, when the percentage of sounds is high, the interference will be low. Another error pronunciation made by the students is the vowels including diphthongs. There were 21 sounds and $3 \%$ of vowel $/ \mathrm{u} /, 4 \%$ of sounds $/ \mathrm{i}: /, / \mathfrak{l} /$, /u:/, /3:/, /ə/, /eI/, /aI/, /əo/, /ı/ and /eə/. There were $5 \%$ of

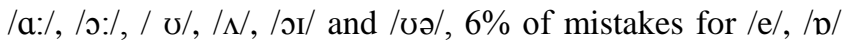
and /av/ and for the last mistake is $7 \%$ of $/ \mathrm{I} /$. In fact, the vowel $/ \mathrm{u} /$ is difficult to pronounce. 
B. The Impact of Mother Tongue Interference to Students' Pronunciation

There are four criteria of mother tongue interference impact made by the students, namely:

\section{Consonant Errors}

In this case, students made pronunciation error in consonants: $/ \mathrm{t} / /, / 3 /, / \mathrm{d} z /, / \mathrm{b} /, / \mathrm{k} / / \mathrm{y} /, / \mathrm{m} /, / \mathrm{v} /$ and $/ \mathrm{d} /$. For example, cabbage $=/ \mathrm{kæbid} / \mathrm{s} /$ some students pronounced /kıbəd/, ka:bed/, /kæbed3/, /kæbed/. Another word like church $=/ \mathrm{t} \int 3: \mathrm{t} f /$, they pronounced /k3:rt/, /t $\mathrm{fu}: \mathrm{t} /$, /kerrt/, /kurt/. It is caused in their first language there is no consonant $/ \mathrm{t} \mathrm{f} /$ and the vowel is interfered by their vowel in first language. In word prestige $=/$ pre'sti:3/, they pronounced /prestig/, /prestik/, /perestig/, /prestiz/. When student pronounced judge $=/ \mathrm{d}_{3} \Lambda \mathrm{d} 3 /$, they made it to be /dzudz/, /dzuk/, /dzeh/, /dzun/. They did not change the vowel of the word because in their first language to pronounce $/ \mathrm{u} /$ is $/ \mathrm{u} /$ too. It also happened in the word cover $=$

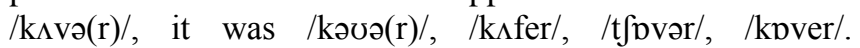
Moreover, not only unchanging vowel they used /v/ like /f/, but they also make no difference between consonant $/ \mathrm{v} /$ and /f/. In word carrot $=/{ }^{\circ} \mathrm{kær} ə \mathrm{t} / \mathrm{some}$ students made it to be /keret/, kerət/, /kıret/, /kıro:t/. In the word larger = /la:dzə/, there were students spelled /la:rge/, /le dzər/, /leiger/, /la:rd/. The word coming $=/ \mathrm{k} \Lambda \mathrm{ming} / \mathrm{students}$ spoke $/ \mathrm{ko:ming} /$ and plum $=/ \mathrm{pl} \Lambda \mathrm{m} /$ became $/ \mathrm{plom} /$, bathe $=/ \mathrm{beið} /$, became /bıðə/, /betə/, maze = /meiz/ changed to $/ \mathrm{mes} /$, $/ \mathrm{mez} / / \mathrm{mes} /$.

\section{Vowel Error}

For vowel sounds, students also made mistake, but it was not as many as in consonants sounds. They made error pronunciation in sounds /u/, /i:/, /æ/, /u:/, /3:/, /eI/, /ai/,

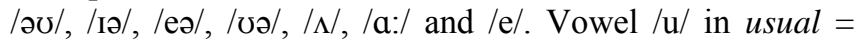
/ju:3uəl/ which pronounced /usəl/, /unsuəl/, /əseil/, /usuəl/, /əsuəl/. The mistake in word cheese $=/ \mathrm{t} f \mathrm{i}: \mathrm{z} /$ which pronounced $/ \mathrm{t} \mathrm{fes} /$, $/ \mathrm{ke} /$. The word antique =/æn'tik/ which pronounced /æntikui/, /æntikiu/, /etik/. The word Food = /fu:d/ they changed to be /fo:d/. The word shirt $=/ \sqrt{3} 3: \mathrm{t} /$ students pronounced /s3:t/, /sirt/, /set/. The word say $=/$ seI/ which was /sai/. When they pronounced buy $=/ \mathrm{bai} /$, it became /bui/, /bei/. The word although =/o:lðəひ/ to be /っ:lðっ:/, / :ltpk/. The same mistake for the word beer = /bıə(r)/ became /ber/, /beər/, /b3:(r)/. For word hair = /heə(r)/, the mistake were /her/, /h3:r/. Word far =/fa:/ some students said $/ \mathrm{f} \Lambda(\mathrm{r}) /, / \mathrm{fa}: \mathrm{r} /$, pull $=/ \mathrm{pol} /$ they pronounced $/ \mathrm{p} \Lambda \mathrm{l} /$. For $h u t=/ \mathrm{h} \Lambda \mathrm{t} /$ and cup $=/ \mathrm{k} \Lambda \mathrm{p} /$ some of students spoke /hot/, /kup/, and / t fup/. In word pure $=/$ pjoə(r) $/$ they pronounced / pju:r/. The word egg $=/$ eg/ they spoke /ig/. It also happened to the other word, students felt confused how to pronounce these words because sometimes the alphabet $u$ would be said $/ \Lambda /, e$ to be /i:, /ai/ became /eə/. However, to understand what they should pronounced is important but sometimes they felt confused what sounds must they use in the word because their first language does not have vowel sounds as many as English. They only know /a/,/ i/, /u/, /e/, /o/ or in English sounds are $/ \Lambda /, / \mathrm{I} /, / \mathrm{v} /, \mathrm{e} /, / \mathrm{p} /$. But the mistake that they made in vowel sounds was smaller than in consonant sounds.

\section{Manner of Articulation Errors \\ 1. Plosives}

The plosives consonants have six sounds but students made mistake in sounds /p/, /b/, /t/, /d/, /k/ and /g/. For the example, happen $=/$ hæpən $/$, the consonant $/ \mathrm{p} / \mathrm{did}$ not make an explosion sound. They said it to be light consonants. Word $\operatorname{bin}=/ \mathrm{bin} /$, student spoke /obin/, it also happened with $t o=/$ tu:/ was like /thu:/, do $=/$ du:/ it was like /dhu:/. When pronouncing hotter $=/ \mathrm{hpt}(\mathrm{r}) /$ and harder $=$ /ha:d(r)/ some students pronounced /ho:tter/ and /hardher/. For word $\cot =/ \mathrm{kpt} /$ they said $/ \mathrm{t} \int \mathrm{pt} /$ and for word $g o t=/ \mathrm{gpt} /$ it became /ghot/, /go:t/.

\section{Nasal}

It was formed by closure complete of lips or by the tongue against palate, the soft palate is lowered and air escapes through the nose or nasal cavity. The sounds are three sounds but students make mistake in sounds $/ \mathrm{m} /$. For example, maze $=/$ meiz/ to be /emeiz/. Actually, this sound is same with their mother tongue but some students made mistake when they pronounced it using the characteristic of consonant sounds but most students pronounced it started mouth was little bit opened and then closure is complete.

\section{Place of Articulation Errors}

Many students could not pronounce words well indirectly but actually there were some errors that have been made. The mistake is how they pronounce the characteristic of consonants that can be divided into:

\section{Dental}

The consonants are the tip tongue against the upper teeth. This characteristic is the tip tongue is used between the teeth of close to the upper teeth. They are $/ \theta /$ and $/ ð /$. Unfortunately, the students made mistake when they spoke using this consonants. The students are pronounced like alveolar characteristic $/ \mathrm{t} /$ and $/ \mathrm{d} /$ for example, theater $=$ $/ \theta$ rote(r)/ became / teate(r)/, bathe $=/$ beið/ was $/$ ba:te/, and this $=/$ ðis/ became /dis/.

\section{Palato-alveolar}

This sound is articulated by the blade of the tongue against the teeth ridge with missing the main body of the tongue towards the palate. It is like the blade (or tip) of the tongue is used just behind the alveolar ridge. They are four sounds yet some students made mistake in consonant $/ 3 /$ and / $/$ /.In addition, they made it like consonants in alveolar /s/. For example, vision $=/ \mathrm{vizn} /$ became $/ \mathrm{vIsn} /$. The consonant $/ \mathrm{J} /$ in the word cash $=/ \mathrm{kæ} \int /$ they said $/ \mathrm{kes} /$.

\section{E. The Factors of Mother Tongue Interference}

The factors influencing the mother tongue interference are the environment where they live. The 
students are mostly surrounded by the Javanese people. Hence, it affects students communication as the first language. The next reason is school area, the teacher could not control students for not using their mother tongue language in classroom school but students still used it when they talked with their friend. Moreover, some students had high accent of mother tongue when they spoke in English. It made their pronunciation was affected by their first language.

For consonant errors they made big mistake in $/ 3 /$ and $/ \mathrm{t} \mathrm{f} /$. In pronouncing consonants respondents often get difficulty in plosive and nasal sounds. In pronouncing plosive sounds $/ \mathrm{p} /, / \mathrm{t} /, / \mathrm{k} /, / \mathrm{d} /, / \mathrm{g} /$ they produce without explosion sound and for nasal they could not pronounce $/ \mathrm{m} /$. There are different symbols in naming of the sounds which the same uttering ways. The differences of symbols make students feel confused how to pronounce it because the symbols are not familiar in their mother tongue language. For the other cases, the consonant sounds will change based on the word like large it pronounced /la:dz/. In students mother tongue especially in Javanese language they do not know it well. So, they stated some English consonants based on the written words in the paper, /la:dz/ to be /large/.

\section{F. The Significance of Understanding the Language Interference for the EFL Teachers}

The overuse of mother tongue language in the communicative foreign language classroom would give some beneficial instruments the EFL teachers [3]. For the the teacher as the example, it will be easier to explain when teaching grammar is posing a conceptual difficulty. Therefore, the illustration by using mother tongue equivalent can be another way that can be done to solve the students' understanding on the materials. On the other hand, it would be considered fundamentally for English teachers to understand the mistakes made by their students. Furthermore, when they meet with non-native speaker of English, whether in Business or travelling, it would simply matter. The awareness of the types of mistakes that learners make and why they do so, will train themselves to learn to understand each other better.

\section{CONCLUSION AND RECOMMENDATION}

Based on analysis that has been done, it can be concluded that the students' mother tongue interference gives effect in their pronunciation. Javanese as mother tongue interference is as an external factor in independent variable that can change one language to the other language and it makes some obstacles when someone learns the other languages. Meanwhile, pronunciation is dependent variable that can change because of mother tongue interference, it is the way students utter the other language in different sounds and available rules as one of speaking aspects to make communication clearly in foreign language especially English. Unfortunately, mother tongue interfered students' pronunciation highly, so that they made mistake in different form because of some factor, they are the highest interference of their first language, the differences of sounds between English and their mother tongue.

The mistake in consonants sounds caused mother tongue interference high. The pronunciation in manner of articulation was high in consonants $/ \mathrm{p} /, / \mathrm{t} /, / \mathrm{d} /, / \mathrm{k} /, / \mathrm{g} /$ in plosive and $/ \mathrm{m} /$ in nasal. For place of articulation, students made mistake $/ \theta /$ and $/ ð /$ in dental and $/ 3 /$ and $/ \mathrm{J} /$ palatoalveolar. The factors of mother tongue interference in students' pronunciation is the environment, students' motivation, different sounds and different sound symbol. Therefore, the kind of interference is the indication of dominant transmigration from the other cultures. Javanese for example, as the language which caused phonic interference and this interference causes changing English pronunciation in their intonation and articulation. Another factor is frequency of speaking Javanese as students daily activities.

\section{References}

[1] Careless, D. (2008). Student use of the mother tongue in the task-based classroom. ELT Journal, Volume 62, No. $4,331-337$.

[2] Carlos, J. J., \& Karina, M. S. (2016). Mother Tongue Phonological Interference In English Language Speech. Academic Unit of Administrative And Humanistic Science, Technical University Of Cotopaxi , 5 .

[3] Cristina. (2012). Overusing Mother Tongue In English Language Teaching. Cultural And Linguistic Communication Vol 2 No. 3 , 212-218.

[4] Denizer, E. N. (2017). Does Mother Tongue Interfere in Second Language Learning? Journal of Foreign Language Education and Technology, 39-54.

[5] Deterding, D., \& Mohamad, N. R. ( 2016 ). Spelling pronunciation in English. ELT JOURNAL Vol 71 (1), 87-91.

[6] Dinar, A. A. (2016). Influence of the Semantic Aspects of Mother Tongue on Learning English as a Foreign Language. Sudan University of Science and Technology Collage of Graduate Studies College of Languages - Department of English , 4.

[7] Dwinastiti, M. (2013, April 2). Language Interference . Dipetik March 2017, 29, dari voila! c'est Alin!: https://marlindwinastiti.wordpress.com/2013/04/02/lan guage-interference/

[8] Gutierrez, A., Pilotti, M., Mahamane, S., \& Broderick, T. (2012). Proactive interference between languages: Do task demands matter? International Journal of Bilingualism Vol 17 Issue 4, 505 - 524.

[9] Keshavarz, M. H., \& Abubakar, M. K. (2017). PRONUNCIATION PROBLEMS OF HAUSA SPEAKERS OF ENGLISH. International Online Journal of Education and Teaching (IOJET), 4(1). , 61-72. 
[10] Labov, W. (2003). Some Sociolinguistic Principles". In Paulston, Christina Bratt; Tucker, G. Richard. Sociolinguistics: the essential readings. WileyBlackwell.

[11] Manrique, C. (2013). Mother Tongue Interference with Foreign Language: A Case Study About A2 Oral Production in a Columbian Public University. Columbia: Columbian Public University.

[12] Mede, E., Tutal, C., Ayaz, D., Çalışır, K., \& Akın, Ş. (2014). The Effect Of Language Transfer in Turkish EFL Learners:. ELT Research Journal 3(2) , 70-83.

[13] Pathan, M. M., Aldersi, Z. E., \& Alsout, E. A. (2014). Speaking in their Language: An Overview of Major Difficulties Faced by the Libyan EFL Learners in
Speaking Skill. International Journal of English Language \& Translation Studies , 96-105.

[14] Sinha, A. (2009). Interference of first language in the acquisition of second language. . Journal of Psychology and counseling, 118-122. , 118-122.

[15] Wahyuni. (2016). The Effectiveness of Demonstration Method Through Audio Visual Media to the Students' Speaking Ability. Mandar Social Science Journal , 4054.

[16] Watcharapunyawong, S., \& Usaha, S. (2013). EFL Students' Writing Errors in Different Text Types: The Interference of the First Language. English Language Teaching; Vol. 6, No. 1. 